\title{
On the Issue of Tungus Component in the Traditional Clothing of Dolgans: Even-Dolgan Parallels
}

\author{
Anatoly I. Savvinov* \\ Institute for Humanities Research \\ and Indigenous Studies of the North of SB RAS \\ 1, Petrovskogo Str., Yakutsk, \\ Sakha Republic (Yakutia), 677007, Russia
}

Received 09.03.2016, received in revised form 12.05.2016, accepted 21.07.2016

The Dolgans is the northernmost small-numbered Turkic speaking people, mainly living in the North of the Krasnoyarsk Territory, as well as in Anabar ulus of the Republic of Sakha (Yakutia). Dolgans' traditional activities are reindeer herding, hunting and fishing. The number of Taimyr and Anabar Dolgans according to the latest population census of 2010 is 7885 people. Typological features of traditional Dolgan clothing are studied in the article. Despite its indigenous basis, in Dolgan clothing, as well as in Dolgan culture as a whole, the presence of different ethnic traditions can be quite clearly traced. According to the comparative analysis undertaken, the archaic elements of the traditional Dolgan clothing are closely related to the ancient Tungus tradition. The closest typological and artistic parallels are found with the traditional clothing of the Evens. The presence of archaic Tungus elements in the traditional Dolgan clothing is largely determined by the ancient ethnogenetic ties of the Dolgans' ancestors with the Tungus world. This article is merely an attempt to address such a serious issue of comparative study of typological features of the traditional clothing of the peoples of the North, which has not been sufficiently studied yet.

Keywords: Dolgans, Evens, traditional clothing, ethnic history, cultural genesis, typology of culture, common traditions, ethnogenetic connections.

DOI: 10.17516/1997-1370-2016-9-10-2482-2489.

Research area: culture studies.

The process of the Dolgan culture formation took place under conditions of constant inter-ethnic contacts, intense ethnocultural mutual influences and interconnections. As a result of long-term economic and cultural exchange Dolgans could create an original, and in its essence, unique type of ethnic culture, formed on the basis of regional characteristics.

The history of the Dolgan culture study is not very long. Although many generations of researchers has always been interested in Dolgan subject. As early as in the 1920s, when the issues of their ethnicity and origin were still very

(C) Siberian Federal University. All rights reserved

* Corresponding author E-mail address: savvin_06@mail.ru 
unclear, there were often disputes about them. Even at that time the researchers traced Even elements in the culture of Dolgans. For example, according to Professor A.N. Maksimov's opinion, "Dolgans are a branch of the so-called Lamut that went this far in the North West" (Dolgikh, 1929). Another well-known authority in the field of the northern peoples' ethnography V.G. Tan-Bogoras considered Dolgans, as well as Chuvans and Yukagirs to be the most Western pro-Asians (Bogoras, 1928). These assumptions were primarily caused by the unique and poorly studied culture of Dolgans, which, at that time, was an ethographic enigma in a lot of ways.

In this article, devoted to the Dolgan traditional clothing the author will try to consider rather than a simple question of the Dolgan-Evenk parallels that can be important in determining ethnic peculiarities of the Dolgan clothing. Traditional clothing is usually the most stable element of material culture that preserves ethnic peculiarities, but depending on various circumstances (change of ethno-cultural environment and geographical conditions) it can easily be changed, transformed and subjected to other cultural influences.

The Historical and Ethnographic Atlas of Siberia (1961) contains materials on the Siberian clothing typology, for the first time undertaken by N.F. Prytkova. For this purpose the author took individual parts (outerwear and headwear) of the traditional clothes of 30 Siberian peoples. Five types of outerwear and eight types of headwear were identified. The cut was the basis for the characteristics of the types of clothing. According to this typology, Dolgan swing outerwear refers to two types (type III - Central Siberian and type V - Lena/Yakut). Basic characteristics of type III clothing is a whole, tailored from a single skin back and straight converging flaps. Only Dolgan men's outerwear refers to this type. Multivariate Lena type (type V), in contrast to the type III, is characterized by straight back with the cutting in the waist, determined by a special cut of sleeves' armholes and side panels. The author referred only Dolgan men's clothing to it as well. For some reason the author has not considered blank clothing of Dolgans. In the other researches by N.F. Prytkova devoted to the study of Samoyed and Paleo-Asiatic peoples' clothing, Dolgan clothing is also repeatedly mentioned as a comparative material.

In ethnocultural terms, historically, Taimyr territory is a special contact zone. This point of three large Siberian language groups' contact: Samoyed, Tungus and Turkic is represented by the Nenets, the Enets, the Nganasans, the Evenks and the Yakuts. All of them, despite their own historical past and various preserved cultural traditions have long coexisted and influenced each other. Since the Dolgan culture, as already noted, has absorbed the peculiar characteristics of ethnocultural traditions of their neighbors, first, the attempt to consider the features of the traditional clothing of these peoples will be made.

There is a lack of details about Dolgan clothing in A.A. Popov's field materials, the topic is almost not affected in the other publications of the scientist, but he suggested some valuable observations about its peculiarities. For example, he first supposed similarities between the Dolgan and the Even (Lamut) clothing. In particular, he wrote that "men's Dolgan clothing gravitated towards the Evens' one where it was both male and female" (Popov, 1956). However, referring to the lack of material and, in general, to the lack of ethnographic study of the latter, he found it impossible to give a more detailed comparison (Popov, 1958). Thus, A.A. Popov noted that "men's outerwear mukaalkaan that has two ornamented triangular wedges in the lower part of the back closely resembles one of the types of the Evens' clothing. Two types of tiuhiuliuk- 
aprons (male and female) differ from the Evenki aprons, both in form and in the arrangement of the patterned embroidery and also bear a resemblance to the Evens' ones" (Popov, 1958). The samples of aprons from MAE mentioned in this study, are actually more similar to the Even than Evenki. The second one even has decorative embroidery in the form of an inverted clinch at the lower part. This detail vaguely reminds the characteristic feature of the Even aprons ornamented composition called urden-herden. This composition, consisting of a rectangle-valve (urden), skillfully embroidered with white and colored reindeer hair and framing it ornamented bands (herden) of rectangular shape as well, in the past, according to the testimonies of the Even informants, had a particularly sacred meaning. This detail, and especially its ornamentation, allowed to "read" different information about the apron's holder (for example, their age, belonging to the family, marital status, presence of children, etc.).

Unfortunately, the Evens culture, especially its ethnolocal variants is still poorly studied in many ways. There isn't a specific study devoted to the Evens clothing yet. It is known that it is very diverse and heterogeneous. According to N.F. Prytkova's typology the Evens outerwear refers to I (Yenisei) and II (Eastern Siberia) types that (as she considered) represent the most ancient clothing of Siberian peoples. A characteristic feature of the Evens variants of these types is that the back of clothing consists of one whole skin with the seams on the shoulders; there are wedges of a triangular or rectangular shape in the back. The area of these types in Siberia is quite large; their variants are common among almost all the western and eastern groups of the Evenki and can be found among the Yukagirs, the Negidals, the Oroks and the Orochi. Developing a typology of Siberian clothing, N.F. Prytkova concluded that the types of clothing corresponded to the specific forms of economic activity, in particular, the above-mentioned types of clothing were worn by hunters and fishermen (HEAS, 1961).

V.L. Seroshevsky in his works devoted to the Yakuts, repeatedly used Tungus, more precisely, Lamut material. They also contain quite a few interesting notes about the Evens clothing. In particular, he wrote: “... the work on the Tunguska costume is striking by its simplicity, almost primitive. Tunguska dress is always cut from one whole buckskin. To give it a proper shape, wedge shaped pieces are inserted in this whole skin under the armpits and two wedges behind at the buttocks. The sleeves are made in the absolutely different manner. In the front side, due to its narrowness, the dress edges do not converge or converge with great difficulty, what makes apron dalys necessary.... It is possible that formerly the skin was put on when it was wet and it was punched only when it took the form of the body; now it is sewn from the tumbled skins" (Seroshevsky, 1993).

A.A. Popov in his assumption did not specify what kind of the Evens clothing and its peculiar characteristics he had in mind, however, indeed, in the main design features of the Dolgan clothing, especially in its archaic forms, there is a lot in common with the Evens clothing. V.H. Ivanov considers swing clothing (kaftan) to be the most common type of shoulder Evens clothing for all seasons (Ivanov, 2001). As well as V.L. Seroshevsky, he notes that the peculiarity of the Even fur kaftan's (teta) cut was the fact that it was sewn from a whole skin that covered the back, sides and partially chest. On the back below the waist two expanding clothes triangle wedges were sewn in the form of deep inverted pleats. S.N. Nikolaev describes such an ancient form of the Evens clothes, made almost from one deerskin and characterized by primitive cut. It was cut in a way that the leather from the upper part of the front legs, cut as a stocking, acted as sleeves 
(Nikolaev, 1964). Such cut can be traced back to the ancient forms of male kaftan mukaalkaan studied by A.A. Popov. It should be noted that the Dolgan name mukaalkaan with the word base muka is nothing more than a diminutive form of this word. Word muka is widely known in many dialects of the Even and Evenki language as the outer winter kaftan with fur outside (History and Culture of the Evens ..., 1997). In some groups of the Evenki the word retained its archaic meaning - skin from the deer's neck (EvenkiRussian Dictionary ..., 1958). Thus, the ancient Tunguska name of the fur outerwear muka that was widely used among Dolgans, evidences not only about its Tungus origin, but also confirms the ancient ethnogenetic connection of Dolgans with the Tunguska world.

In general, the main peculiar features of the Evens' traditional kaftan are: not converging on the chest flaps of the kaftan, fitted silhouette, round collar on threading and narrow sleeves with the sewn mittens have a lot in common with the Dolgan outerwear. In rare old photographs Dolgan types of narrow kaftans with barely converging flaps and tied rovduga straps-bindings can be seen. Rovduga chest plates are clearly visible under the kaftans. A lot of characteristics of the Evens' kaftan can be found in the Dolgan outerwear. Decorative details should be particularly noted. The edges of the Dolgan elegant fur coats hanyiak have decorative vertical stripes, almost identical to those of the Evens' kaftans teta, made in accordance with the technique of fur mosaic (Even. ele). Ancient Dolgan fur coats as well as the Evens' kaftans had two ornamented valves at the back, located above the wedges (Even. ukchan) (Ivanov, 2001). Wide extensions of the bottom hem, extended back, etc. can be considered as peculiar features of the Dolgan and Evenki kaftans. In addition, similar traditional techniques of decoration are used for the Dolgan and Evens clothing decoration: fur mosaic, embroidery with reindeer neck hair, decoration with the seal pup fur painted in red color (Evens), or hare feet (Dolgan), etc. In addition to these techniques of decorating, colored beads without which it is difficult to imagine smart Evens' clothes, are widely used. The Evens even had a specific type of embroidered kaftan called nisami or nihamchi, which is translated as beaded (Even nisa beads, bugles) (Nikolaev, 1964). The ornament of the Evens clothing is simple and small, mainly consisting of patterns of bands. A characteristic feature of both the Evens and Dolgan clothing is strict compositional structure of the ornament. Footwear and headwear decor in the nature of the pattern, the technique of its arrangement and color scheme is strictly combined with the kaftan design, making a single ensemble.

The obligatory element of the Dolgan clothing are aprons that, if not to take into account some specific features of decoration - technique and the nature of ornament, as well as the material, in its design features are typologically very close to Even. Thus, A.A. Popov in his publications noted that the Dolgan aprons in their design features are really the closest to Even, consisting as if of two parts: the upper one - chestplate of trapezoid shape as such and the lower one - a broad strap (of apron), often of quadrangular shape. The lower part is the most decorated in the Even apron. According to V.Kh. Ivanov's materials, the Even aprons belong to type II and have the following characteristic features: the shape of apron (pinafore) is narrow in its upper part, with a neck cut, widening in the middle, it is usually cut of two pieces of skin or rovduga, less often of one piece of rovduga (Ivanov, 2001).

The main type of Even headwear is hood consisting of three parts. This type of hood was also the most common among Dolgans. In addition, it should be considered as more archaic than the other variant, consisting of two parts, as it is well known, borrowed from the Nenets. 
The round shape of the Even hood tightly fitting the head, the general nature of the décor and furry at the edges have a lot in common with the design and artistic features of the Dolgan hoods, in the decor of which white reindeer neck hair embroidery and beaded lines are symmetrically arranged on the main seams (Savvinov, 2005 ).

In the course of the comparative analysis a lot of terminology parallels that characterize traditional Dolgan clothing are found in the Even lexis. The Evens generally call winter fur coat (men's and winter) muka and winter hood intika. The Evens also call home footwear tebun. Dolgan not open clothing dunduk kopoo made of white low wool deerskins with the fur outside, is nothing else than the name of the ancient Even clothing dudyka or dudika. Lamunkhin and Sakkyryr Evens call footwear with long tops urguld'u, as well as Dolgans, gaiters are also called khutoro. In general, in everyday vocabulary referring to the Dolgan clothing it is possible to find a lot of words that have direct parallels in the Even language (Savvinov, 2005).

The Even traditional clothing, which has a wide territory and a lot of regional variants carries rich ethnic and cultural traditions of the northern reindeer herders' costumes, their study in comparative terms is of extraordinary interest, and the materials could give answers to many questions. Perhaps, the Even clothing tradition contains the most archaic features and the ancient origins of the Tunguska costume. Although it is known that at one time the Even clothing experienced significant influence of the neighboring peoples traditions: the Yakuts from the one side and the Chukchi-Koryak from the other. In general, the Even elements in the Dolgan costume are obvious enough, though, as we know, Dolgans didn't have direct contacts with the Evens. The very rare connection was possible through the Anabar and Bulun Yakut reindeer herders. The existing similarities between the
Dolgan and Even clothing are not random, as evidenced by historical materials; the Dolgans' ancestors had direct ethnogenetic connections with the Even families, as evidenced by the names of many of them. Concerning this issue B.O. Dolgikh wrote: "At that, it should be noted that the Even elements of culture are more visible among western and especially South-Western Norilsk Dolgans and to a lesser extent in the territories of North-Eastern Dolgans in the lower reaches of the Popigay and Anabar. Such strange, at first glance, circumstance is explained by the fact that North-Eastern Dolgans experienced long-term and strong influence of Yakut reindeer herders of North-Western Yakutia and, therefore, the aforementioned Even traits in their material culture are less noticeable" (Dolgikh, 1963).

To have a closer look into the essence of the problem it is necessary to address to the ethnogenetical data that can give a broader understanding of the peculiarities of the Dolgans' ethnic origin. B.O. Dolgikh who dedicated his work, based on the study of archival materials of the $17^{\text {th }}$ century, to this problem, revealed a number of interesting facts about the origin of Dolgans. According to the historical sources, there were no Dolgans in the $17^{\text {th }}$ century in Taimyr. According to the author, the Tunguses of Dolgan family that Russians found in the $17^{\text {th }}$ century at the Lena River, between the mouths of the Aldan and Vilyui, that initially payed tribute to Ust-Vilyui wintering place, were the ancestors of the part of Dolgans, who gave name to the Dolgan people (Dolgikh, 1963). They lived in yurts on the right bank of the Lena and were engaged in fishing. For the first time Russian Cossacks took tribute from this group of the Dolgans' ancestors in 1631-1962 (Dolgikh, 1963). These Lena Tunguses of the Dolgan family at that time nomadised in the two groups. The northern ones occupied the territory of the mouth of the Muna River and initially 
paid tribute to Stolbovoye wintering place at the mouth of the river. These Tunguses were known as the Tunguses of the Nemchansky family (Dolgikh, 1963). In the late $17^{\text {th }}$ century most of the Ust-Vilyui Dolgans and the Kumkagirs moved to Olenek, where they were united by a single name of the Tunguses of "Dolgatsky family". According to the author, these were the ancestors of the contemporary Dolgans of the former Dolgan-Esey council (Dolgikh, 1963).

The next step in the history of the former Ust-Vilyui Dolgans was their relocation to the Mangazeysky (Turukhansk) County that in the $17^{\text {th }}-18^{\text {th }}$ centuries also included the territory of modern Taimyr. It is possible to assume that in the $60 \mathrm{~s}$ of the $18^{\text {th }}$ century when this group of Dolgans settled in the territory of modern Taimyr, the most of the population had already spoken the Yakut, but knew the Tungus language as well. Thus, Tungus migration with the Dolgans tribal name took place from the Lena River to Khatanga basin, where they became the main constituent element of the future Dolgan ethnicity (Dolgikh, 1963). Thus, B.O. Dolgikh made the assumption that in the $17^{\text {th }}$ century the Dolgans were a tribe of the near Lena Tungus, consisting of several parts, which were closer to the Evens (Dolgikh, 1963). He believed that the ancestors of the part of Dolgans, that gave the name to the Dolgan people, were those Tunguses of the Dolgan family that the Russians found on the Lena River in the $17^{\text {th }}$ century (Dolgikh, 1963).

Now it is necessary to focus on the Dolgan family Tunguses, who started to appear on the Okhotsk coast in the late $17^{\text {th }}$ century, in 1678 there were about 240 people. In the late $18^{\text {th }}$ century according to the tribute audit, four administrative Dolgan families were found there (History and Culture of the Evens ..., 1997). B.O. Dolgikh did not recognize the possible existence of direct genetic links between these geographically dispersed groups, and considered the Okhotsk Evens who did not have direct relation to the Dolgan people formation, but only noted that this fact could be an indication of the dialect proximity and the character of generic names formation for both of these groups (Dolgikh, 1963). Unfortunately, we do not have reliable historical data about the further fates of these Dolgan groups of the Evens ${ }^{1}$. However, as an assumption we can say that these groups were once a part of the nearLena Dolgan families that moved off as early as in the $17^{\text {th }}$ century, and it is quite possible that their ancestry, after all, had a lot in common with them. In general, it is possible to say that, apparently, Dolgan ancestors had inherited the culture of those distant Tungus relatives and its echoes could be preserved in the traditional clothing of the Taimyr Dolgans.

Thus, the undertaken preliminary comparative analysis evidences that the archaic types of the traditional Dolgan clothing in its design and technological features are quite close to the traditions of the Evens' clothing. According to the materials, the available parallels between the traditional types of the Dolgan and Even clothing are interconnected in many ways by their common ethnic roots and the presence of the archaic Tunguska component in the Dolgan culture. This peculiarity is quite noticeable and can be traced in the other elements of the spiritual and material culture of Dolgans. In general, the range of issues referred to in the article is an important problem that requires a comprehensive approach to its study, involving a wider range of sources.

It should be noted that at the present time the generic name of the Dolgans has preserved among Okhotsk, Magadan and Kamchatka Evens. Among the indigenous population of these administrative areas there are a lot of modern Evens with the Dolgan family name. 


\section{References}

Bogoraz, V.G. Novye dannye k voprosu o protoasiatakh [New Data to the Issue of Proto-Asians], In Ezvestiia Leningradskogo universiteta [Bulletin of Leningrad University], 1928, 235 - 243.

Dolgikh, B.O. Naselenie poluostrova Taimyr i prilegauchshego k nenu raiona [Population of the Taimyr Peninsula and Adjacent to it Area], In Severnaia Asia [North Asia], 1929, 2, 49-76.

Dolgikh, B.O. Proiskhozhdenie dolgan [The Origin of the Dolgans], In SES [SED]. M, 1963, 5, 92-139.

Ivanov, V. Kh. Etnokul'turnye vzaimosviazi i vzaimovliianiia u narodov Sevara-Vostoka Sibiri [Ethnocultural Interconnections and Mutual Influences of Peoples of the North-East of Siberia]. Novosibirsk, Nauka, 2001, 155 p.

Prytkova, N.F. Verkniaia odezhda [Outerwear], In Istoriko-etnographicheskii atlas Sibiri [The Historical and Ethnographic Atlas of Siberia [HEAS]]. M, L., 1961, 489 p.

Istoriia i kul'tura evenov. Istoriko-etnographicheskie ocherki [History and Culture of the Evens. Historical and Ethnographic Essays]. SPb, Nauka, 1997, 227-328.

Nikolaev, S.I. Eveny i Evenki Uigo-Vostochnoi Yakutii [The Evens and the Evenks of the SouthEastern Yakutia]. Yakutsk, 1964, 204p.

Popov, A.A. Dolgany [Dolgans], In Narody Sibiri [The Peoples of Siberia], Edited by M.G. Levin, L.P. Potapova. M., L., 1956, 1082 p.

Popov, A.A. Kollektsii po material'noi kul'ture dolgan v MAE [Collections on the Material Culture of the Dolgans in MAE], In SMAE [JMAE]. M., L., 1958, 5-121.

Savvinov, A.I. Problemy etnokul'turnoi identifikatsii dolgan. Na materialakh traditsionnogo iskusstva [Problems of the Dolgans' Ethnocultural Identification. On the Traditional Art Materials]. Novosibirsk, Nauka, 2005. 310 p.

Seroshevsky, V.L. Iakuty: Opyt etnographicheskogo issledovaniia [The Yakuts: Ethnographic Study Experience]. M., ROSPEN, 1993, 1, 713 p.

Evenkiisko-russkii slovar' [Evenki-Russian Dictionary]. Compl. by G.M. Vasilevich. M., 1958, $802 \mathrm{p}$.

\section{К вопросу о тунгусском компоненте \\ в традиционной одежде долган: \\ эвено-долганские параллели}

Долганы - самый северный малочисленный тюркоязычный народ, в основном проживающий на Севере Красноярского края, а также в Анабарском улусе Республики Саха (Якутия). Традииионными занятиями долган являются оленеводство, охота и рыболовство. Численность таймыр- 
ских и анабарских долган, по данным последней переписи населения 2010 года составляет 7885 чел. В статье рассматриваются типологические особенности традиционной одежды долган. Несмотря на самобытную основу в долганской одежде, как и в иелом в культуре долган, достаточно ярко прослеживаются некоторые напластования различных этнических традииий. Как показывает предпринятый сравнительный анализ, архаичные элементы традиционной одежды долган тесно связаны с древней тунгусской традииией. Наиболее близкие типологические и художественные параллели обнаруживаются с традиционной эвенской одеждой. Наличие архаичных тунгусских элементов в традииионной одежде долган во многом объяснимо древними этногенетическими связями предков долган с тунгусским миром. Данная статья является лишь попыткой затронуть столь глубокую проблему сравнительного изучения типологических особенностей традищионной одежды народов Севера, которая еще недостаточно изучена.

Ключевые слова: долганы, эвены, традиционная одежда, этническая история, культурогенез, типология культуры, общность традищий, этногенетические связи.

Научная специальность: 24.00.00 - культурология. 